\title{
A REVIEW OF MILD COMBUSTION AND OPEN FURNACE DESIGN CONSIDERATION
}

\author{
M.M. Noor ${ }^{1}$, Andrew P. Wandel ${ }^{1}$, and Talal Yusaf ${ }^{2}$ \\ ${ }^{1}$ Computational Engineering and Science Research Centre, \\ Department of Mechanical and Mechatronic Engineering \\ University of Southern Queensland (USQ), Australia \\ ${ }^{2}$ National Centre for Engineering in Agriculture, USQ, Australia \\ Email: Muhamad.MatNoor@usq.edu.au
}

\begin{abstract}
Combustion is still very important to generate energy. Moderate or Intense Low-oxygen Dilution (MILD) combustion is one of the best new technologies for clean and efficient combustion. MILD combustion has been proven to be a promising combustion technology in industrial applications with decreased energy consumption due to the uniformity of its temperature distribution. It is clean compared to traditional combustion due to producing low $\mathrm{NO}_{\mathrm{x}}$ and $\mathrm{CO}$ emissions. This article provides a review and discussion of recent research and developments in MILD. The issue and applications are summarized, with some suggestions presented on the upgrading and application of MILD in the future. Currently MILD combustion has been successfully applied in closed furnaces. The preheating of supply air is no longer required since the recirculation inside the enclosed furnace already self-preheats the supply air and selfdilutes the oxygen in the combustion chamber. The possibility of using open furnace MILD combustion will be reviewed. The design consideration for open furnace with exhaust gas re-circulation (EGR) was discussed.
\end{abstract}

Keywords: MILD combustion; turbulent combustion; open furnace.

\section{INTRODUCTION}

Energy security is becoming more important since the use of energy has been a key in the development of the human society and concern over the depletion of the fossil fuel reserves. With the current supply and demand, the fossil fuel will be depleted by 2042 (Shafiee and Topal, 2009). The demand of energy is dramatically increasing due to the growth of the world's population and the substantial economic development in countries such as South East Asia, China and India. Chemical reactions through combustion still contribute to most energy needs. Some of the major challenges are in providing efficient energy and limiting greenhouse-gas (GHG) emissions. The combustion of fossil fuel is projected to fulfill about $80 \%$ of these energy requirements (IEA, 2009; Maczulak, 2010). Combustion pollution is linked to an increase in the earth's temperature, unstable weather, increase in the ocean levels and ice melting in the North and South Poles. The more efficient use of fuel with low GHG emissions as well as carbon capture and storage (CCS) might be effective ways to gradually reduce GHG emissions (IEA, 2006, 2009; Orr, 2005). IEA/OECD (2002) and Jonathan (2006) reported that $\mathrm{CO}_{2}$ contributed $77 \%$ of the GHG emissions, with combustion accounting for $27 \%$, making it a major contributor to global climate change. To counter this issue, the improvement in combustion efficiency with lower emissions has led researchers to focus on new 
combustion technology and combustion modeling (Merci et al., 2007; Smith and Fox, 2007). One of the methods to improve combustion efficiency is to preheat the reactant by a hot flue gas. However, preheating the combustion air generally increases the flame temperature which results in greater formation of thermal $\mathrm{NO}_{\mathrm{x}}$. A new combustion technology has been invented that is able to solve this issue: Moderate or Intense Lowoxygen Dilution (MILD) combustion, which produces high combustion efficiencies with very low emissions.

Combustion processes require three elements: fuel, oxidizer, and a heat or ignition source. Before the ignition process, the fuel and oxidizer need to be mixed at a molecular level via a turbulent mixing process. Wünning (1991) observed a surprising phenomenon during experiments with a self-recuperative burner. At furnace temperatures of $1000^{\circ} \mathrm{C}$ and about $650^{\circ} \mathrm{C}$ air preheat temperature no flame could be seen and no UV-signal could be detected. The fuel was completely burnt and the exhaust $\mathrm{CO}$ was below $1 \mathrm{ppm}$. The $\mathrm{NO}_{\mathrm{x}}$ emissions were almost zero, with smooth and stable combustion. Wünning (1991) called that condition "flameless oxidation" or FLOX (Milani and Wünning, 2007; Wünning, 1996; Wünning and Wünning, 1997). This new combustion technology was also named MILD combustion (Cavaliere and de Joannon, 2004; Dally et al., 2002). Katsuki and Hasegawa (1998) and Tsuji et al., (2003) found that high-temperature air combustion (HiTAC) is nearly the same as MILD combustion, besides operating at higher temperatures. MILD combustion has many beneficial features, especially in the production of a uniform temperature distribution, excellent combustion stability, very high efficiency and extremely low emissions of $\mathrm{NO}_{\mathrm{x}}$. Some history, recent trends and research on MILD are reviewed in this paper. The key topics discussed include the MILD combustion mode and regime, MILD combustion flame characteristics and properties, $\mathrm{NO}_{\mathrm{x}}$ and soot emissions, and MILD combustion burners. Discussion on the recommendations and future possible direction of MILD combustion are put forward based on the demands of industry.

\section{MILD COMBUSTION REGIME}

The temperature of the reactant must be higher than the mixture's self-ignition temperature (Table 1), so the recirculation of hot flue gas to preheat the reactants and simultaneously dilute oxygen is a key concept of MILD combustion (Tsuji et al., 2003). The maximum temperature increase due to combustion is lower than the mixture's selfignition temperature (Cavaliere and de Joannon, 2004).

Recent applications of MILD combustion have been in the research and development of gas turbines (Arghode and Gupta, 2010a, 2010b, 2011a, 2011b; Duwig et al., 2008) and gasification systems (Tang et al, 2010, 2011). This combustion mode can be very interesting in gas turbine applications due to the low maximum temperatures (very close to those at the inlet of a gas turbine), noiseless characteristics, good flame stability and effectiveness in reducing pollution emissions. In contrast, the problems related to the large scale application of MILD gas turbines are the characteristic time related to the chemical process (the ignition delay time) and the preheating of the fresh reactants (ultralean, superdiluted, highly preheated). Based on the study and review by Li et al. (2011b), common MILD combustion appears to be summarized as:

i) High temperature pre-heating of combustion air and the high-speed injection of air and fuel are the main requirements of achieving MILD combustion; 
ii) Strong entrainments of high-temperature exhaust gases, which dilute the fuel and air jets, are the key technology for maintaining MILD combustion;

iii) Important environmental conditions for the establishment of MILD combustion: local oxygen concentration less than $5-10 \%$ while local temperature is greater than that of fuel self-ignition in the reaction zone. These must be achieved by the strong dilution of reactants with the flue gas $\left(\mathrm{N}_{2}\right.$ and $\mathrm{CO}_{2}$-rich exhaust gases);

iv) When using the regenerator to recycle the waste heat of flue gases, the thermal efficiency of MILD combustion can increase by 30\%, while reducing $\mathrm{NO}_{\mathrm{x}}$ emissions by $50 \%$ (Tsuji et al., 2003).

Table 1. Summary of different combustion modes (Cavaliere and de Joannon, 2004)

\begin{tabular}{lcc}
\hline \multicolumn{1}{c}{ Combustion mode } & Inlet conditions & \multicolumn{1}{c}{$\begin{array}{c}\text { Working } \\
\text { conditions }\end{array}$} \\
\hline $\begin{array}{l}\text { Mild Combustion (MILD) } \\
\begin{array}{l}\text { High Temperature Air Combustion } \\
\text { (HiTAC) }\end{array}\end{array}$ & $\mathrm{T}_{\mathrm{in}}>\mathrm{T}_{\mathrm{si}}$ & $\Delta \mathrm{T}<\mathrm{T}_{\mathrm{si}}$ \\
Feedback Combustion & $\mathrm{T}_{\mathrm{in}}>\mathrm{T}_{\mathrm{si}}$ & $\Delta \mathrm{T}>\mathrm{T}_{\mathrm{si}}$ \\
\hline
\end{tabular}

MILD combustion is substantially different from normal combustion, mainly because of the low oxygen concentration (3-13\%) and a mixture temperature that is higher than the fuel's autoignition point ( $\mathrm{Li}$ et al., 2011b). The supply air needs to be heated using a recuperator or regenerator to absorb the waste heat from the flue gas. A recuperator can preheat the air to $1000 \mathrm{~K}$, while a regenerator can heat the combustion air to about $1600 \mathrm{~K}$ (Tsuji et al., 2003). There are four main regimes: a clean MILD combustion region, where MILD is easily sustained without any significant emissions; an unstable flame region, where low-emission MILD conditions can be achieved by suitably selecting some key operating parameters, such as the combustion air temperature; a conventional (normal) flame combustion region and a no-combustion or extinction zone. The more usual representations (Cavigiolo et al., 2003; Wünning and Wünning, 1997) identify different regimes of stable and unstable flame combustion and a flameless oxidation region. Figure 1 shows the comparison of MILD flame and conventional flame. Figure 2 indicates that the MILD combustion range for oxygen dilution ratio is about 2.5 and above and the reactant temperature is above the selfignition temperature.

The oxygen concentration and temperature of the preheated air will affect the MILD flame color, as shown in Figure 3. The flame becomes green and generally less visible when the oxygen level decreases to 2\% (Gupta et al., 1999). Parente et al. (2009, 2011) studied the MILD combustion regime using a novel methodology based on Principal Component Analysis (PCA), investigating the main features for its characterization. PCA can effectively identify low dimensional representations of the $\mathrm{CH}_{4} / \mathrm{H}_{2}$ experimental dataset Figure 4 illustrates the flame region for MILD and conventional combustion based on $[\mathrm{OH}]$ contours. Significantly, both the reacting and non-reacting zones for the MILD case are bigger compared to the conventional case. 

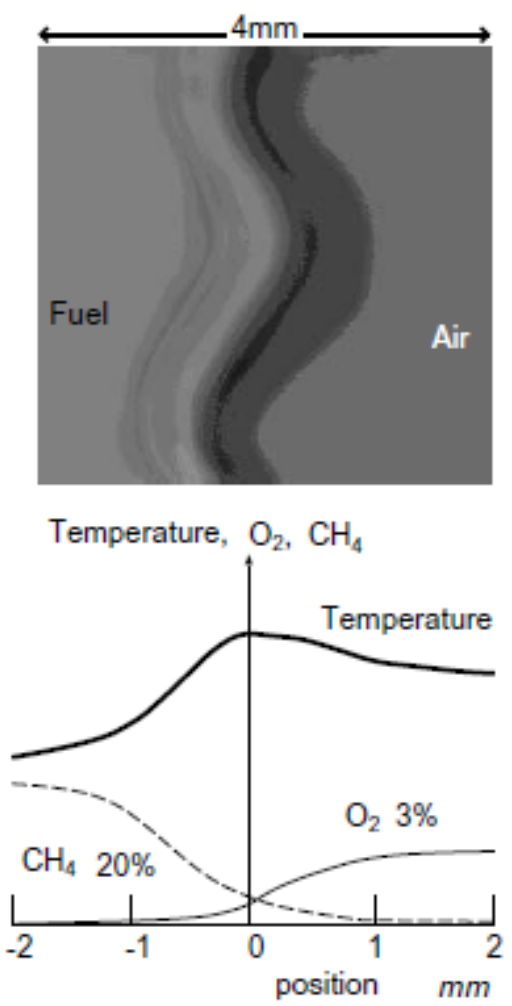

(a)

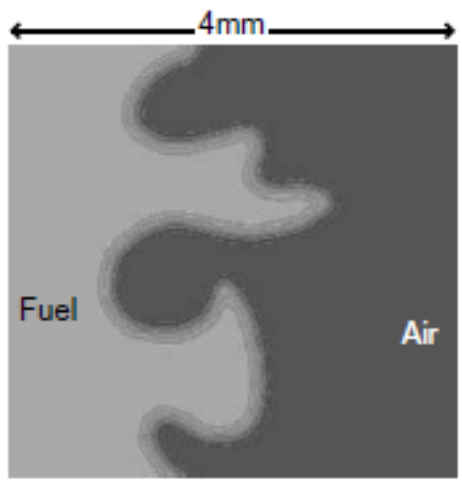

Temperature, $\mathrm{O}_{2}, \mathrm{CH}_{4}$

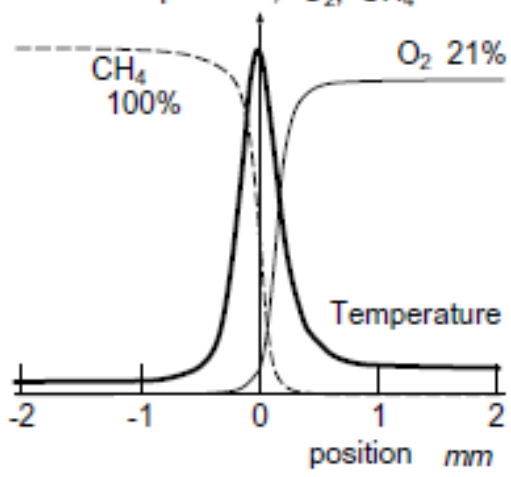

(b)

Figure 1. Comparison of the temperature and mass fraction (a) MILD combustion (b) conventional combustion (Tsuji et al., 2003)

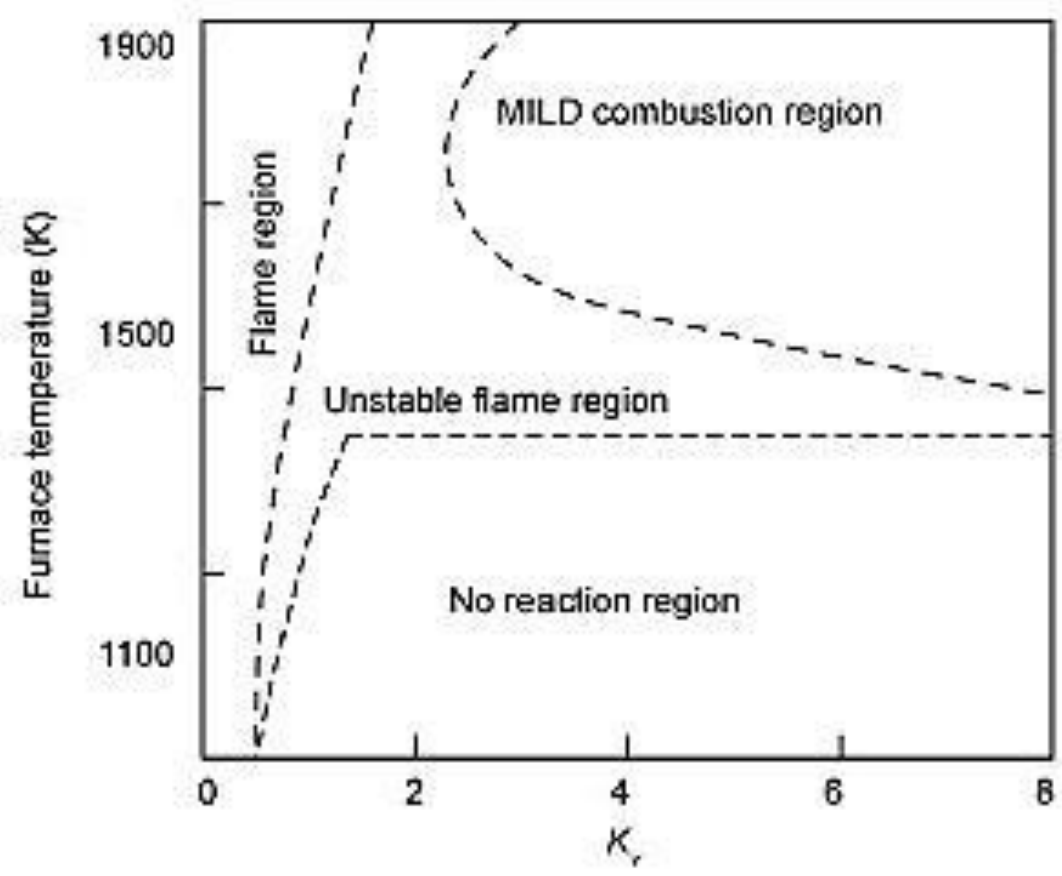

Figure 2. The relationship between furnace temperature and dilution ratio (Wünning and Wünning, 1997) 


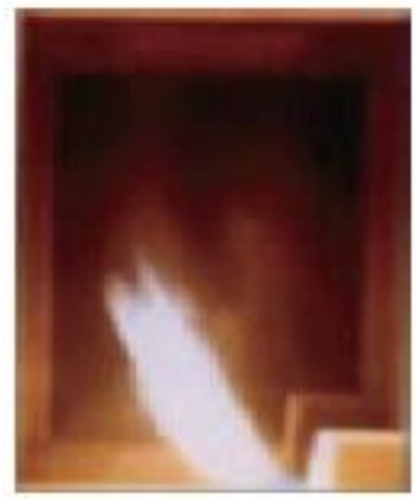

(a) $21 \%$

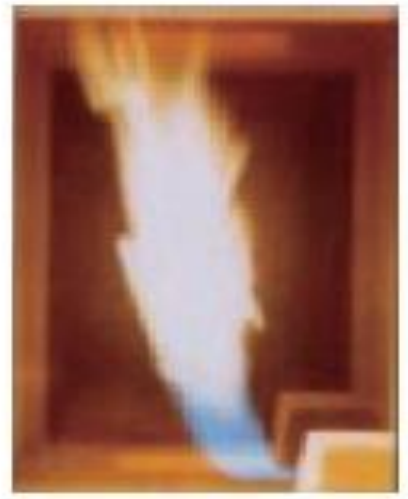

(b) $8 \%$

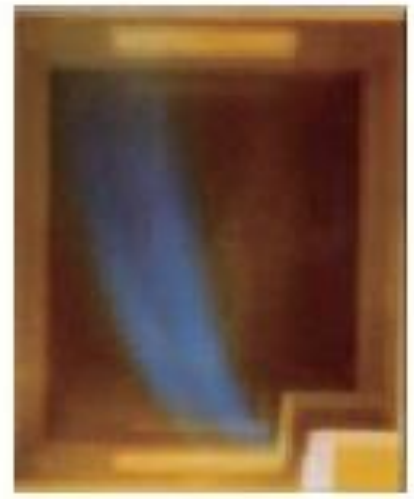

(c) $2 \%$

Figure 3. Combustion air temperature of $1100{ }^{\circ} \mathrm{C}$ and percentage of $\mathrm{O}_{2}$ concentration (Gupta et al., 1999)

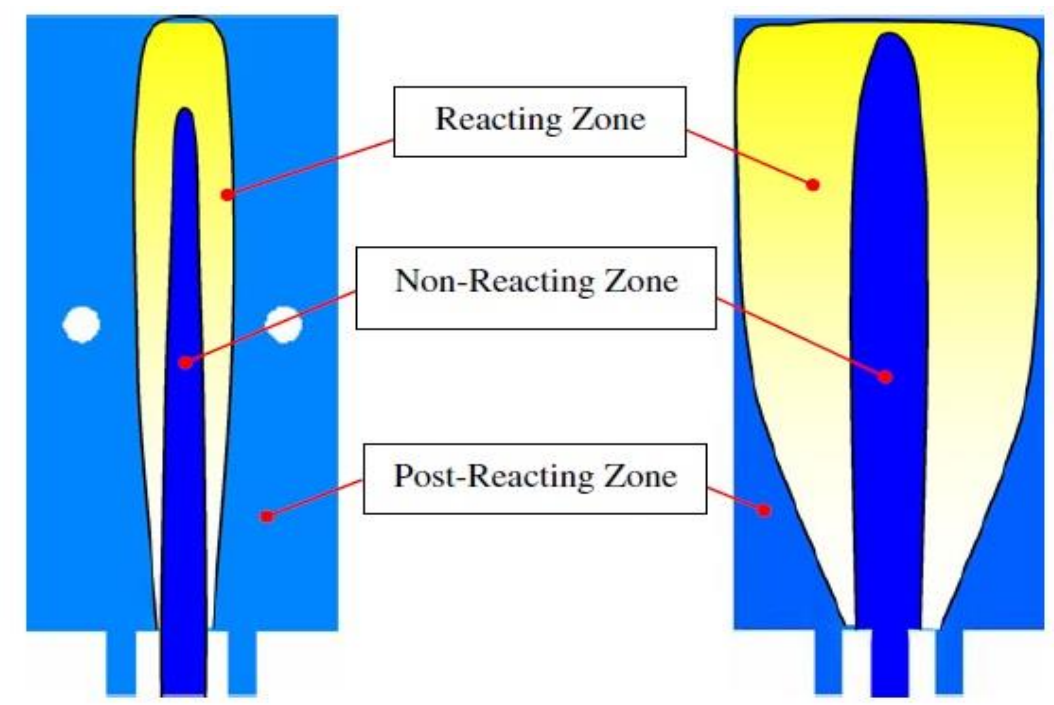

(a)

(b)

Figure 4. Closed furnace reacting zone for (a) conventional and (b) MILD combustion ( $\mathrm{Li}$ and $\mathrm{Mi}, 2011)$

\section{COMBUSTION EFFICIENCY}

Efficiency is very important for combustion process. Combustion efficiency is the ratio of the heat received by the target material to be heated (useful output) to the supply heat provided to the combustor (in the form of electricity or fuel supply). Industrial burners need a stable and efficient flame for an economic and safe heating process. At an industrial scale, diffusion or non-premixed combustion is commonly used due to its controllability and safety (Peters, 2000; Tsuji et al., 2003). Bluff-body burners can offer a stable burner as required. There are many different shapes and geometries, such as cone, cylinder, vee gutter, disk and sphere. The geometry will affect the recirculation zone (flame bluffing zone). Furnace efficiency is defined as the ratio of heat received by the target material to the heat supplied by the furnace heater. A lean and clean operation of the furnace is critical, since two-thirds of the plant's energy budget is allocated to the 
cost of fuel (Thomas, 2011). Combustion thermal efficiency in the furnace can be improved by recycling the exhaust gases (Li et al., 2011a, 2011b). Further understanding of the flame structure is necessary to widen the range of application of MILD combustion (Medwell, 2007), especially research on open furnaces.

MILD combustion has been proven to produce clean and efficient combustion. Recent studies by Colorado et al. (2009) and Danon, de Jong and Roekaerts (2010) on low-calorific-value fuels used in MILD combustion show that low $\mathrm{NO}_{\mathrm{x}}$ emissions were achieved. The fundamental parameters of MILD combustion are the average combustion chamber temperature $\left(\mathrm{T}_{\mathrm{c}}\right)$, dilution ratio $\left(\mathrm{K}_{\mathrm{V}}\right)$, and jet velocity (Derudi et al., 2007a). $\mathrm{K}_{\mathrm{V}}$ is a key parameter for MILD combustion working conditions. Several other researchers (Cavigiolo et al., 2003; Galletti et al., 2009; Katsuki and Hasegawa, 1998; Wünning and Wünning, 1997) defined $\mathrm{K}_{\mathrm{V}}$ as the ratio between the recycled exhaust and the incoming air and fuel flow rates. MILD combustion has many advantages, such as producing very high thermal efficiencies and low $\mathrm{NO}_{\mathrm{x}}$ emissions. It produces a uniform temperature distribution, excellent combustion stability and has been considered one of the new-generation of clean and efficient combustion technologies. It has great potential to be implemented in many industrial applications. The early research and development of MILD combustion came from Germany (Kim et al., 2008; Mancini et al., 2002; Mancini et al., 2007; Plessing et al., 1998; Wünning and Wünning, 1997; Zieba et al., 2010) and Japan (Katsuki and Hasegawa, 1998; Tsuji et al., 2003; Yuan and Naruse, 1999).

When MILD combustion starts, the furnace is bright and transparent (Cavaliere and de Joannon, 2004; Tsuji et al., 2003; Wünning and Wünning, 1997). The advantages of MILD combustion are already reaching industry: Danon (2011) reported an increase in demand for expertise on the implementation of MILD combustion, especially for large-scale furnaces equipped with multiple burners. MILD combustion has been achieved experimentally (Cabra et al., 2003, 2005; Derudi and Rota, 2011; Derudi et al., 2007a, 2007b, 2007c; Ertesvag and Magnussen, 2000; Hasegawa et al., 2002; Kraus and Barraclough, 2012; Kumar et al., 2007; Li and Mi, 2010; Li et al., 2010a, 2010b; Mi et al., 2010; Mörtberg et al., 2007; Oldenhof et al., 2010, 2011; Özdemir and Peters, 2001; Rafidi and Blasiak, 2006; Sabia et al, 2007; Weber et al., 2000; Yuan and Naruse, 1999; Zhenjun, Tong and Chaohua, 2010) and numerically (Awosope et al., 2006; Cabra et al., 2003, 2005; Coelho and Peters, 2001; De et al., 2010; Ertesvag and Magnussen, 2000; Frassoldati et al., 2010; Galletti et al., 2009; Kim et al., 2005; Kraus and Barraclough, 2012; Kumar et al., 2007; Oldenhof et al., 2010; Parente et al., 2011; Parente et al., 2011; Park et al., 2003; Szegö, 2010; Zhenjun et al., 2010) in premixed, partially-premixed and non-premixed combustion modes. For furnace combustion, a simultaneous increase in the radiant heat transfer and reduced $\mathrm{NO}_{\mathrm{x}}$ emissions is possible with careful control of the fuel and air mixing (Mulliger and Jenkin, 2008). Nakamura et al. (1993) and Webber (2001) experimentally studied several pilot-scale furnaces equipped with heat exchangers. They demonstrated that the port angles and locations will affect heat transfer.

Combustion with and without exhaust gas recirculation (EGR) will be measured and analyzed for comparison. This data will be used to determine the efficiency improvement. Figure 5 shows the comparison of combustion with and without EGR. The furnace in Figure 5(a) is running without a regenerator (EGR) and with 654 BTU of heat lost through the flue gas. The difference in Figure 5(b) is that the furnace is running with a regenerator (EGR), and from $654 \mathrm{BTU}$ of heat in the flue gas only $133 \mathrm{BTU}$ is lost through the flue gas to the atmosphere. Some 521 BTU of heat is returned to the 
system through the use of the regenerator. For the same amount of fuel input into the system, $37.4 \%$ efficiency for the system without EGR and $72.4 \%$ for the system with EGR are achieved. EGR will reduce $\mathrm{NO}_{\mathrm{x}}$ emissions of the oxygenated fuels by more than 55\% since it reduces both the pressure (Raj and Sendilvelan, 2010) and the maximum temperature.

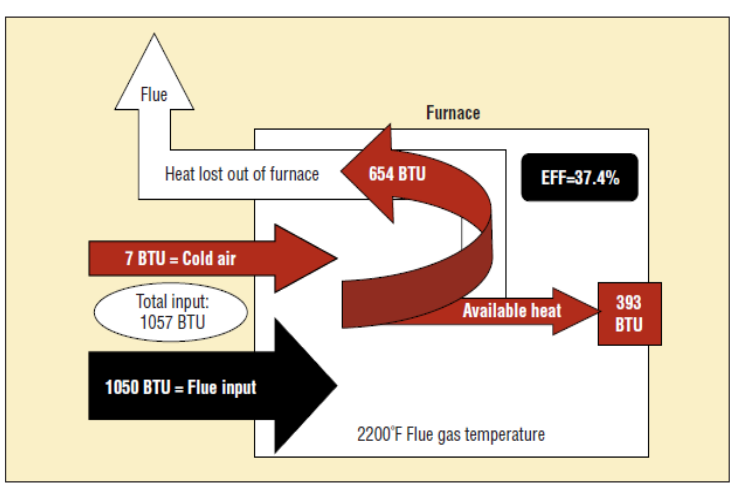

(a)

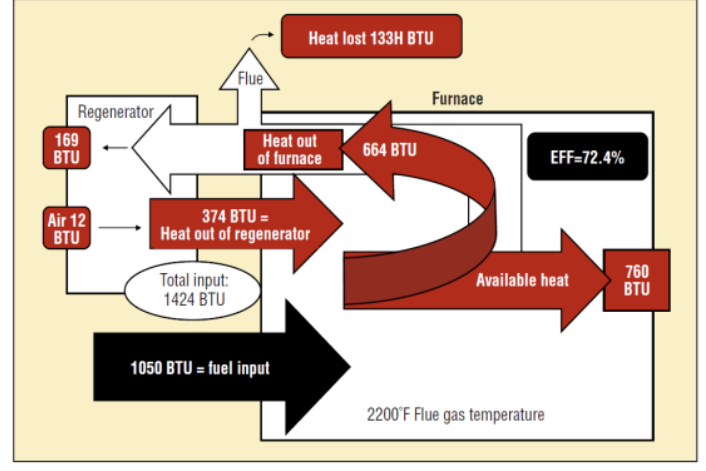

(b)

Figure 5. Efficiency of the heating system (a) without EGR (b) with EGR (Kraus and Barraclough, 2012).

\section{RECENT TRENDS IN MILD}

Recent experiments have successfully achieved MILD combustion using industrial waste as a fuel. Dally et al. (2010) injected sawdust into a MILD closed burner and achieved MILD state. Although the concept of MILD combustion has been extensively studied experimentally and numerically, the challenge to accurately model the MILD combustion regime is due to the homogeneous mixing field and slower reaction rates. MILD combustion is characterized by a strong relation between turbulence and chemistry, occurring in similar timescales (Galletti et al., 2007; Plessing et al, 1998). The turbulence-chemistry interactions should be treated with finite rate approaches. The non-premixed mode occurs when the fuel and preheated air are injected into the enclosure furnace through different ports, and mixing and combustion proceed inside the chamber. Parham et al. (2000) reported that by controlling the mixing through their precessing gas jet, a simultaneous reduction in $\mathrm{NO}_{\mathrm{x}}$ emissions of $30-50 \%$ and an increase in heat transfer of $2-10 \%$ were achieved. Szegö et al. (2008) used a furnace with $20 \mathrm{~kW}$ supplied by the fuel and $3.3 \mathrm{~kW}$ from the pre-heated air. This closed furnace used parallel air and fuel jets with one central air nozzle, four fuel jets and four exhausts. All the nozzles and exhausts were at the bottom of the furnace. This MILD combustion setup has produced data on various experiments, including fuel tests, flame tests, $\mathrm{NO}_{\mathrm{x}}$ tests, and heat exchanger tests (Christo and Dally, 2005; Colorado et al., 2009; Dally et al., 2002, 2004, 2010; de Joannon et al. 2009, 2010; Flamme, 2004; Li et al., 2011b; Lou et al., 2007; Maruta et al., 2000; Medwell et al., 2007, 2008; Mi et al., 2009; Mörtberg et al., 2006; Oryani et al., 2011; Park et al., 2004; Stankovic, 2006).

MILD combustion technology is still not fully commercialized and well adopted in the furnace industry, thus it is very important to conduct substantial fundamental and applied research (Cavaliere et al., 2008; Danon, 2011; Li et al., 2011b; Parente et al., 2011a, 2011b). The fuel-air mixing in MILD combustion has become a topic of interest 
(Tsuji et al., 2003). The precise prediction of turbulent mixing is important in the modeling of turbulent combustion because it has a great effect on the flow field and turbulence-chemistry interaction (Shabanian et al., 2011). Galletti et al., (2007) claimed that the reactants' jet velocity and angle are the main parameters affecting the quality of the air-fuel mixture. The characteristic of MILD combustion is the strong coupling between turbulence and chemistry (Parente et al., 2008) occurring at similar timescales (Galletti et al., 2007; Plessing et al., 1998), thus the turbulence-chemistry interactions should be treated with finite-rate approaches. The level of homogeneity of the mixing field (de Joannon et al., 2010) and slower reaction rates make the accurate modeling of this combustion regime challenging (Aminian et al., 2011), especially regarding the heat release rate and $\mathrm{NO}_{\mathrm{x}}$ and soot formation, thus a fundamental study on the mixing quality is required. To achieve MILD combustion the air supply has to be preheated (Wünning and Wünning, 1997). Many researchers claim that regenerative heating or preheating is an important element in MILD combustion applications, which may add some complexity when retrofitting systems. However, a recent study by Li et al. (2011a, 2011b) showed that preheating is not required in the case of a closed furnace. The use of an open furnace operating in MILD combustion mode will be discussed. Generally, the setup for an open furnace is simpler and cheaper than a closed furnace, because the latter needs a thick and solid wall. However, open furnaces have an additional complexity because of their requirement for preheating (Li et al., 2011a, 2011b). Oldenhof et al. (2011) claimed that studying flameless combustion in an open and unconfined setup might provide valuable insights. The combination of open furnace and preheating as well as the effect of air-fuel mixing (Oldenhof et al., 2011) need to be fully addressed. It is believed that there is no reported data about MILD combustion in open furnace applications.

Biogas is an attractive alternative to replace the dependency on fossil fuels. Colorado et al. (2009) studied MILD combustion using biogas (methane diluted with inert gases), and reported that $\mathrm{NO}_{\mathrm{x}}$ and soot emissions were reduced but $\mathrm{CO}$ emission was increased. This was possibly due to the high fuel dilution and low coflow oxygen level. $\mathrm{NO}_{\mathrm{x}}$ emissions could be reduced effectively by means of low-oxygen concentration combustion (Fuse et al., 2002; Gupta, 2000; Suzukawa et al., 1997). $\mathrm{NO}_{\mathrm{x}}$ strongly depends on the mixing processes between fuel and air. The recirculation flue gases are entrained with combustion air and fuel before combustion occurs to depress higher peak temperatures, suppressing thermal $\mathrm{NO}_{\mathrm{x}}$. There are a few quantities that must be measured and analyzed when MILD is achieved, such as the combustion dilution ratio $\left(\mathrm{K}_{\mathrm{V}}\right)$ and temperature inside the combustion chamber. The dilution ratio must be measured in order to achieve a MILD combustion regime. The minimum dilution ratio to achieve MILD combustion is 2.5 (Wünning and Wünning, 1997). The temperature of steady-state combustion must comply with the working-condition temperature, as shown in Table 1. The key control strategy of MILD combustion is the heating requirement of the furnace. Based on the heating requirement, the dilution ratio and fresh air supply will be controlled. EGR, fresh air and fuel supplies are controlled based on the dilution ratio required. Fuel consumption is the key to measuring the efficiency of the system. Thermocouples will be used to measure the heat produced from the flame. The comparison of combustion with and without EGR will be measured and analyzed. This data will be used in efficiency improvement. 


\section{EXHAUST GAS RECIRCULATION}

The thermal efficiency of the furnace and other heating equipment, such as kilns, ovens and heaters, is the ratio of heat received by the target material and heat supplied to the heating equipment. A large amount of heat is wasted in the form of flue gases and a small amount in wall losses, opening losses, store heat and cooling water losses. The design, operation and maintenance of the heating equipment are key factors in these losses. EGR is one method to recover these losses. EGR behaves differently to heat regenerators. EGR works by recirculating a portion of the exhaust gas back to the combustion chamber. The main purpose of EGR is that the oxygen in the combustion chamber will be diluted by the hot flue gas and the mixture will be directly heated. The volume of hot flue gas to inject back into the system depends upon the level of oxygen dilution needed. EGR with MILD combustion was used by Wünning and Wünning (1997), Katsuki and Hasegawa (1998) and Cavaliere and de Joannon, (2004) as a solution to avoid $\mathrm{NO}_{\mathrm{x}}$ and soot formation. Wünning and Wünning (1997) calculated the dilution ratio $\mathrm{K}_{\mathrm{V}}$ with $\mathrm{EGR}$ as:

$$
K_{V}=\frac{M_{E}}{\left(M_{F}+M_{A}\right)}=\frac{\left(M_{T}-M_{F}-M_{A}\right)}{\left(M_{F}+M_{A}\right)}
$$

The total mass flow rate $\left(\mathrm{M}_{\mathrm{T}}\right)$ is calculated by adding the EGR mass flow rate $\left(\mathrm{M}_{\mathrm{E}}\right)$, fuel mass flow rate $\left(\mathrm{M}_{\mathrm{F}}\right)$ and fresh air mass flow rate $\left(\mathrm{M}_{\mathrm{A}}\right)$. The dilution ratio $\left(\mathrm{K}_{\mathrm{v}}\right)$ and temperature inside the combustion chamber are measured when combustion achieves steady state. The minimum dilution ratio is 2.5 (Wünning and Wünning, 1997). The control strategy is the heating required by the furnace, which will determine the required dilution ratio. Thermocouples are used to measure the heat produced from the flame. The damper blade will act as a control valve at the furnace stack. The damper blade will be used to control the outflow from the furnace, and the percentage of the opening size will determine the percentage of EGR. The EGR and the fresh air mixing will determine the dilution ratio of the system. The total flue gas out of the system must be equal to the quantity of fresh air and fuel supply.

\section{BIOGAS}

Biogas is a low heating value gas also known as low calorific value gas. Considering biogas with a standard methane content of $50 \%$, the heating value is $21 \mathrm{MJ} / \mathrm{Nm}^{3}$, the density $1.22 \mathrm{~kg} / \mathrm{Nm}^{3}$ and the mass is similar to air at $1.29 \mathrm{~kg} / \mathrm{Nm}^{3}$ (Al-Seadi et al., 2008). The use of gas is predicted to continue to replace coal for electricity generation as it is a cleaner fuel producing lower GHGs. Coal usage is predicted to increase by $50 \%$, whereas gas is expected to increase by $88 \%$ (Scragg, 2009). Biogas can be produced from the biodegradation of organic materials of biological origin (biomass) in anoxic environments, such as swamps, wetlands, sediments, and in the rumen of ruminant animals. Methane production in engineered anaerobic digestion (AD) systems has been employed for more than a century to treat municipal sludge generated by municipal wastewater treatment plants (WWTPs). Besides being a renewable resource and reducing GHG emissions, biogas also benefits the farmers. It reduces biomass waste, and furthermore digestate is an excellent fertilizer since it is rich in nitrogen, phosphorus and potassium. Besides the many advantages of biofuel and biogas, there are currently certain debates on the sustainability of biofuel resources (RACQ, 2008), 
including the risk to the food supply and the shortage of biomass due to flooding and other circumstances. The energy balance for biogas and natural gas was compared (Table 2) for operation in MILD combustion and conventional modes. The efficiency for the conventional mode is only $41.4 \%$ whereas for biogas and natural gas in MILD mode it is $68 \%$ and $70 \%$ respectively.

Table 2. Biogas and natural gas energy balance (Colorado et al., 2010).

\begin{tabular}{lccc}
\hline \multicolumn{1}{c}{ Combustion mode (fuel) } & $\begin{array}{c}\text { MILD } \\
\text { mode } \\
\text { (biogas) }\end{array}$ & $\begin{array}{c}\text { MILD } \\
\text { mode (natural } \\
\text { gas) }\end{array}$ & $\begin{array}{c}\text { Conventional } \\
\text { mode (natural } \\
\text { gas) }\end{array}$ \\
\hline $\begin{array}{l}\text { Energy input (including } \\
\text { fuel + combustion } \\
\text { air + cooling air) }(\mathrm{kW})\end{array}$ & 21.13 & 21.31 & 21.02 \\
$\begin{array}{l}\text { Energy losses through the } \\
\text { wall (kW) }\end{array}$ & 3.00 & 3.07 & 3.20 \\
$\begin{array}{l}\text { Energy removed by the } \\
\text { cooling tubes }(\mathrm{kW})\end{array}$ & 14.39 & 14.99 & 8.71 \\
$\begin{array}{l}\text { Energy output through } \\
\text { the chimney (kW) }\end{array}$ & 2.72 & 1.39 & 8.25 \\
$\begin{array}{l}\text { Energy of the combustion } \\
\text { products after the } \\
\text { regenerative system }(\mathrm{kW})\end{array}$ & 1.01 & 1.36 & 0 \\
Efficiency $(\%)$ & 68.0 & 70.0 & 41.4 \\
\hline
\end{tabular}

Table 3. The difference in natural gas composition between certain countries (Jonathan, 2006; Kong and Reitz, 2002; Olsson et al., 2002; Papagiannakis and Hountalas, 2004; Hairuddin et al., 2011).

\begin{tabular}{lcccc}
\hline \multirow{2}{*}{ Component } & \multicolumn{4}{c}{$\%$ Volume } \\
& Australia & Greece & Sweden & US \\
\hline Methane $\left(\mathrm{CH}_{4}\right)$ & 90.0 & 98.0 & 87.58 & 91.1 \\
Ethane $\left(\mathrm{C}_{2} \mathrm{H}_{6}\right)$ & 4.0 & 0.6 & 6.54 & 4.7 \\
Propane $\left(\mathrm{C}_{3} \mathrm{H}_{8}\right)$ & 1.7 & 0.2 & 3.12 & 1.7 \\
Butane $\left(\mathrm{C}_{4} \mathrm{H}_{10}\right)$ & 0.4 & 0.2 & 1.04 & 1.4 \\
Pentane $\left(\mathrm{C}_{5} \mathrm{H}_{12}\right)$ & 0.11 & 0.1 & 0.17 & - \\
Hexane $\left(\mathrm{C}_{6} \mathrm{H}_{14}\right)$ & 0.08 & - & 0.02 & - \\
Heptane $\left(\mathrm{C}_{7} \mathrm{H}_{16}\right)$ & 0.01 & - & - & - \\
Carbon Dioxide $\left(\mathrm{CO}_{2}\right)$ & 2.7 & 0.1 & 0.31 & 0.5 \\
Nitrogen $\left(\mathrm{N}_{2}\right)$ & 1.0 & 0.8 & 1.22 & 0.6 \\
\hline
\end{tabular}

Methane is the main component of natural gas and biogas, and is the most abundant organic compound on earth. Natural gas is a promising alternative fuel to meet strict engine emission regulations in many countries. Internal combustion engines that run on natural gas can operate at lean burn and stoichiometric conditions with different combustion and emission characteristics. Table 3 shows the differences in natural gas composition between certain countries. Natural gas, methane or hydrogen are commonly used in industrial burners. The combustion of hydrogen is the cleanest and 
produces very low emissions. Hydrogen's low density makes it challenging to store (requiring very high-pressure tanks). Table 4 shows the properties of natural gas, hydrogen and diesel. By adding hydrogen to the fuel blend, the influence of molecular diffusion will increase with increasing hydrogen (Mardani et al., 2010). Mardani and Tabejamaat (2010), Mardani et al. (2010) and Wang et al. (2011) investigated the effects of hydrogen addition and found that MILD combustion occurred more easily. Yu et al. (2010) found that pure hydrogen could not reduce thermal $\mathrm{NO}_{\mathrm{x}}$ emissions in a flameless combustion regime.

Table 4. Diesel properties compared to hydrogen and natural gas (Liu and Karim 2008; Saravanan and Nagarajan 2010; Saravanan et al., 2008; Verhelst and Wallner 2009; Hairuddin et al., 2011).

\begin{tabular}{lccc}
\hline Properties & Diesel & Hydrogen & Natural Gas \\
\hline Main component & - & - & $\begin{array}{c}\text { Methane } \\
\left(\mathrm{CH}_{4}\right)\end{array}$ \\
Auto-ignition Temperature $(\mathrm{K})$ & 553 & 858 & 923 \\
Lower heating value $(\mathrm{MJ} / \mathrm{kg})$ & 42.5 & 119.93 & 50 \\
Density $\left(\mathrm{kg} / \mathrm{m}^{3}\right)$ & $833-881$ & 0.08 & 692 \\
Molecular weight $(\mathrm{g} / \mathrm{mol})$ & 170 & 2.016 & 16.043 \\
Flammability limits in air $(\mathrm{vol}$ & $0.7-5$ & $4-75$ & $5-15$ \\
$\%)$ & 0.3 & $2.65-3.25$ & 0.45 \\
Flame velocity $(\mathrm{m} / \mathrm{s})$ & 0.83 & 0.091 & 0.55 \\
Specific gravity & $453-653$ & 20.2 & 111.5 \\
Boiling point $(\mathrm{K})$ & $40-60$ & - & - \\
Cetane number & 30 & 130 & 120 \\
Octane number & 13.4 & 0 & 9.5 \\
$\mathrm{CO}_{2}$ emissions $(\%)$ & - & 0.61 & 0.16 \\
$\mathrm{Mass}^{3}$ diffusivity in air $\left(\mathrm{cm}^{2} / \mathrm{s}\right)$ & - & 0.02 & 0.28 \\
Min ignition energy $(\mathrm{mJ})$ & &
\end{tabular}

Hydrogen's properties give it many advantages over fossil fuels. Hydrogen is mainly produced from fossil fuel resources and only $4 \%$ is generated by electrolysis. In the future, when fossil fuels are depleted, the raw material will become water and biomass (Hollinger and Bose, 2008). One of the objectives of these studies is to optimize the burner head design using CFD modeling, which should be validated against experimental results. The purpose of the fuselage (enclosure) is to capture the flue gas to be used as EGR. This configuration is not fully enclosed due to there being an opening at the top of the furnace. Therefore this setup is considered an open furnace.

\section{CFD MODELING}

The earliest CFD modeling for MILD (HTAC) technology originated from the Japanese heating industry where a few researchers (Ishii et al., 1997, Zhang et al., 1997 and Hino 
et al., 1998) conducted simulations on the $\mathrm{NO}_{\mathrm{x}}$ formation for the experimental continuous slab reheating furnace. The application of computer simulation techniques to improve the combustion process has rapidly expanded over the last decade. These techniques offer reliable predictions on the effect of various parameters on combustion performance. Moreover, the computational simulation frequently presents information on physical quantities that are difficult to measure. CFD is the tool for the numerical model: it solves the fluid flow problem and reduces the cost of expensive experimental work. Galletti et al., (2007) reported that besides the experimental characterization of MILD combustion burners, industry has also shown interest in CFD modeling. CFD may help optimize burner performance, by assisting in the design of injection nozzles and flue gas recirculation. CFD alone is not fundamentally strong without validation of its results with experimental work. Different scales of MILD combustion setups have been simulated using CFD software over the last few decades (Danon, 2011).

The configuration of the reactants and exhaust ports was optimized using a CFD modeling study (Szegö et al., 2003). Mollica et al., (2009) used CFD to study the effect of preheating, further dilution provided by inner recirculation and a radiation model for a hydrogen-air MILD burner. Noor et al., (2012a, 2012b, 2012c, 2012d) used CFD to optimize the furnace parameters setup and air fuel ratio before the development of the furnace for experimental testing. Oryani et al. (2011) numerically analyzed and compared flue gas recirculation (FGR) and fuel induced recirculation (FIR) conditions in the case of $\mathrm{N}_{2}, \mathrm{CO}_{2}$ and $\mathrm{H}_{2} \mathrm{O}$ dilution, and found that with small amounts of dilution FIR is more effective in $\mathrm{NO}_{\mathrm{x}}$ reduction. The established model in ANSYS Fluent ${ }^{\circledR}$ will be utilized. The continuous fluid flow and chemical reactions are simulated by discretizing the transport equations. A mesh or numerical grid of the physical geometry of the burner head and boundary wall are generated. The numerical grid divides the physical volume into cells with finite volumes. The fluid flow and heat transfer transport equations, which are the conservation of mass, momentum, heat and species, are solved. Recently Szegö et al. (2011) used CFD to model MILD combustion in a furnace and found that there is a strong coupling between the furnace aerodynamics and the reaction zone. CFD modeling is useful to pre-determine the control parameters. Sensitivity to turbulence models (e.g. standard k- $\varepsilon$ model; Launder and Sharma, 1974) will normally be investigated. The control parameters for modeling are the temperature, velocity and angle of the supply air, the temperature, velocity and angle of the fuel, the percentage of EGR, the location of the EGR input to supply air, the burner head design and fuel properties.

Turbulent flow occurs at high Reynolds numbers in a very complex process and is even more complex when it involves a combustion reaction or other chemical reaction. Tennekes and Lumley (1972) characterized the nature of the turbulence as irregularity, large Reynolds numbers, diffusivity, three-dimensional vorticity fluctuations and continuum phenomenon. In the combustion process, particle interactions are very important in the fuel and air mixing process: the usage of mixing models is required to close the molecular diffusion term in the probability density function (PDF) transport (Pope, 1985):

$$
\frac{\partial \rho \mathrm{P}}{\partial \mathrm{t}}+\frac{\partial \rho \mathrm{u}_{\mathrm{i}} \mathrm{P}}{\partial \mathrm{x}_{\mathrm{i}}}+\frac{\partial \rho \mathrm{S}_{\mathrm{k}} \mathrm{P}}{\partial \psi_{\mathrm{k}}}=-\frac{\partial}{\partial \mathrm{x}_{\mathrm{i}}}\left[\rho\left\langle\mathrm{u}_{\mathrm{i}}^{\prime \prime} \mid \psi\right\rangle \mathrm{P}\right]+\frac{\partial}{\partial \psi_{\mathrm{k}}}\left[\frac{1}{\rho}\left\langle\frac{\partial \mathrm{J}_{\mathrm{i}, \mathrm{k}}}{\partial \mathrm{x}_{\mathrm{i}}} \mid \psi\right\rangle \mathrm{P}\right]
$$

Particle mixing is becoming more important in the study of the mixing process. Recently, Wandel (2011) proposed a new turbulent mixing model which randomizes the interaction of the particles locally. The proposed model was called SPDL or the 
Stochastic Particle Diffusion Length model (Wandel, 2011), which is based upon the practical localness of the random inter-particle distance (Noor, Yusaf and Wandel, 2011). The configuration of reactants and exhaust ports was optimized using a CFD modeling study (Khoshhal et al., 2011; Noor et al., 2012a, 2012b; Szegö et al., 2003). Mollica et al. (2009) used CFD to study a hydrogen-air MILD burner. They reported on the effect of preheating, with further dilution being provided by an inner recirculation and radiation model. A numerical method was utilized for flue gas recirculation (FGR) and fuel induced recirculation (FIR) analyses (Oryani et al., 2011). For small amounts of $\mathrm{N}_{2}, \mathrm{CO}_{2}$ and $\mathrm{H}_{2} \mathrm{O}$ dilution, FIR is more effective in $\mathrm{NO}_{\mathrm{x}}$ reduction. Recently Szegö, et al. (2011) used CFD to model MILD combustion in a furnace and found that there is a strong coupling between furnace aerodynamics and the reaction zone.

\section{OPEN FURNACE}

MILD combustion in a closed furnace has been invented and established for many years, however many fundamentals still need to be studied and resolved. Open furnace combustion for MILD is still a very new approach. Generally, open furnaces are more common in industry and the setup for an open furnace is cheaper than a closed furnace because the latter needs a thick wall. However, open furnaces have additional complexity due to the need for preheating of the reactant. Open furnace combustion needs an enclosed chamber to collect the flue gas and use it as EGR. The oxygen in the fresh air supply needs to be diluted, and EGR must be used for this purpose. The concept of the open furnace is due to the opening at the top of the furnace, and the flue gas that has not been used for EGR will be released from this top opening. Figure 6 shows an open furnace (Noor et al., 2012a, 2012b) used to numerically study MILD combustion. The opening at the top of the furnace chamber can be controlled in order to regulate the amount of EGR and dilution ratio. The dilution ratio will be controlled by the opening of the damper. The damper on the furnace stack will be used to control the outflow from the furnace, and the percentage of opening size will be determined by the percentage of the exhaust gas recirculated (EGR). Table 5 shows the typical data for CFD setup.

Table 5. Typical data for furnace and burner

\begin{tabular}{ll}
\hline \multicolumn{1}{c}{ Item } & \multicolumn{1}{c}{ Data } \\
\hline Fuel & $60 \% \mathrm{CH}_{4}+40 \% \mathrm{CO}_{2}$ \\
Oxidiser & Atmospheric air and syntactic air at room temperature \\
Fuel Inlet & $1 \times 78.5 \mathrm{~mm}^{2}$ \\
Air Inlet & $4 \times 78.5 \mathrm{~mm}^{2}$ \\
Chamber size & Diameter 600mm, Height 860mm \\
EGR & 4 EGR with 1962.5 mm meach inlet $^{2}$ \\
Mesh method & $\begin{array}{l}\text { Tetrahedrons (Patch conforming method) with 111,975 } \\
\text { nodes and 501,831elements }\end{array}$ \\
Radiation model & $\begin{array}{l}\text { Discrete Ordinate (DO) model. Absorption coefficient: } \\
\text { Weighted Sum of Gray Gas (WSGGM) model. }\end{array}$ \\
\hline
\end{tabular}




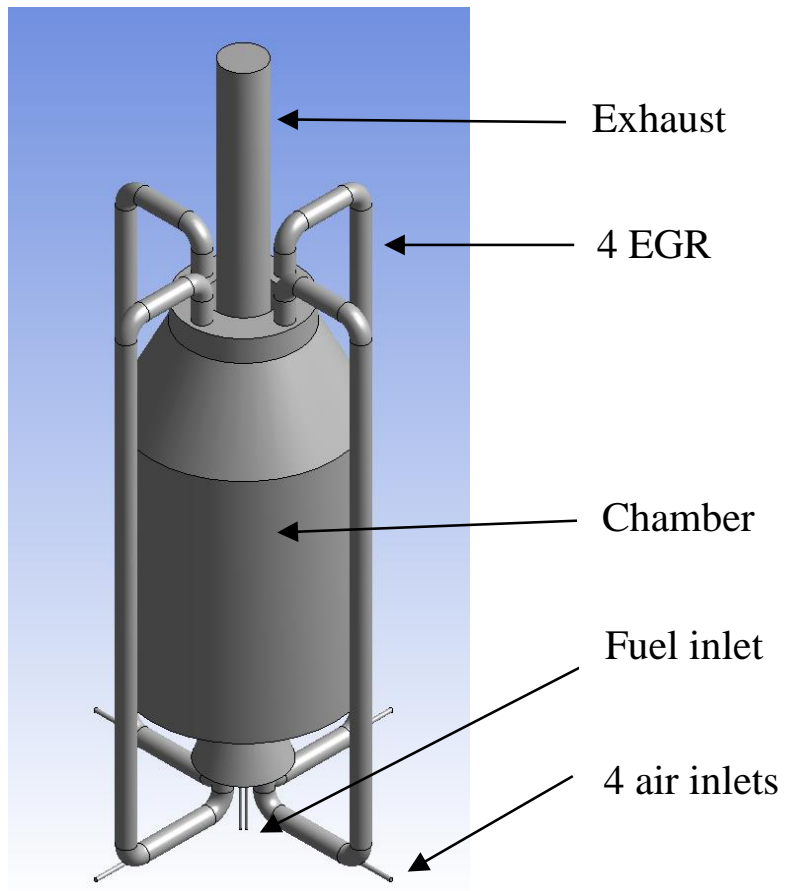

Figure 6. Open furnace with top chamber opening and 4 EGR.

The main purpose of EGR is to dilute fresh air with exhaust gas and therefore reduce the peak combustion temperature and pressure, which will reduce the amount of $\mathrm{NO}_{\mathrm{x}}$ (Abd-All et al., 2001; Agarwal et al., 2006; Hountalas et al., 2008; Santoh et al., 1997). The EGR and fresh air mixing will determine the dilution ratio of the system. The total flue gas out from the system must be equal to the volume of the fresh air supply. In order to capture the combustion image and flame propagation, a high speed camera will be utilized in the early stage of the combustion and establishment phase. When the flame reaches a steady state and is invisible to the naked eye, the high speed camera will capture the flame's luminescence (Oldenhof et al., 2010, 2011). This process is important for the analysis of a MILD combustion non-premixed flame. In normal jet flames, the lift-off height is the axial height of the sharp flame interface. For the MILD flame, to determine the lift-off height a certain threshold level for an averaged quantity is defined. The use of variables such as temperature (Kumar, Paul and Mukunda, 2007), OH concentration (Cabra et al., 2003; Ertesvag and Magnussen, 2000) and luminescence (Cabra et al., 2005) were proposed.

The open furnace is operated with the combination of a few parameters: preheating the reactants using EGR to dilute the oxygen in the air supply, high reactant jet velocity, hydrogen addition to the biogas to reduce the mixture's self-ignition temperature and turbulent mixing of the reactant. Through the optimization of the study's parameters, MILD combustion in an open furnace can be successfully achieved. CFD was utilized to simulate MILD combustion with biogas. Biogas is a low calorific value gas. In this simulation, $60 \%$ methane was mixed with $40 \%$ carbon dioxide to form the low calorific value gas. This ratio of biogas also used by Noor et al. (2012c, 2012d) and Keramiotis and Founti (2013). The initial results for the CFD simulation of combustion temperature and EGR flow are shown in Figures 7,8 and 9. The results of the simulation show that MILD combustion can be achieved using open furnace combustion, with an enclosed chamber to capture and utilize flue gas as EGR. 


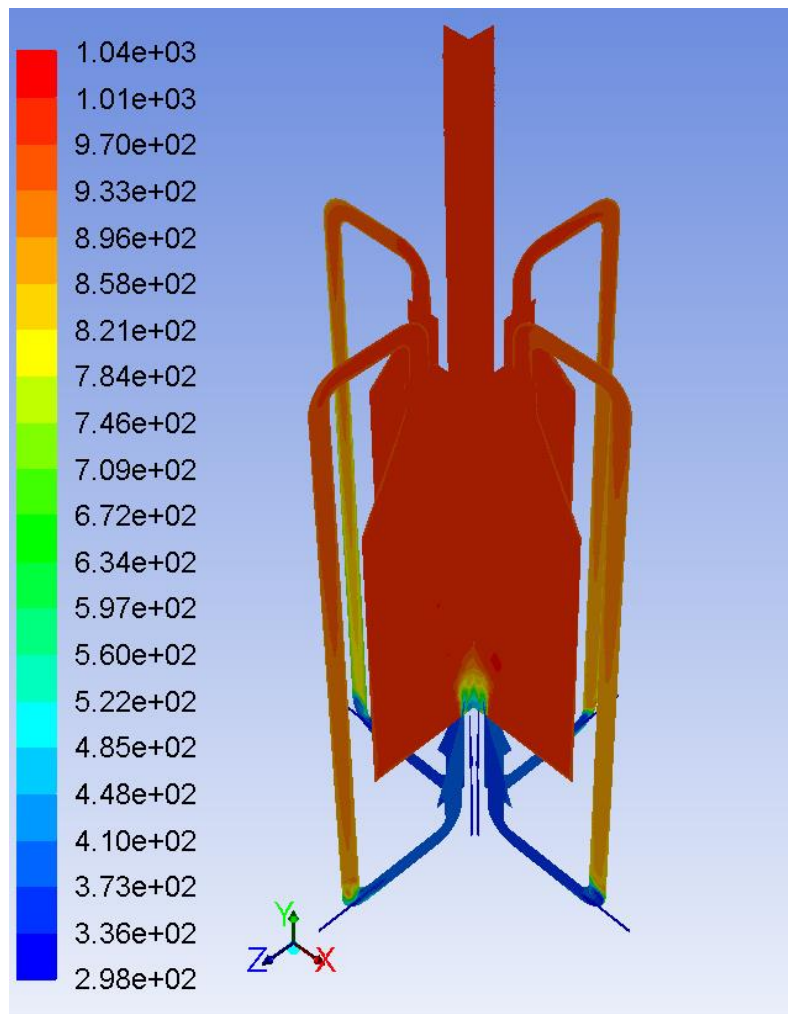

Figure 7. Combustion temperatures reach MILD combustion state for biogas. Syntactic air $\left(11 \% \mathrm{O}_{2}\right)$ inlet at $20 \mathrm{~m} / \mathrm{s}$ and fuel inlet at $9.5 \mathrm{~m} / \mathrm{s}$.

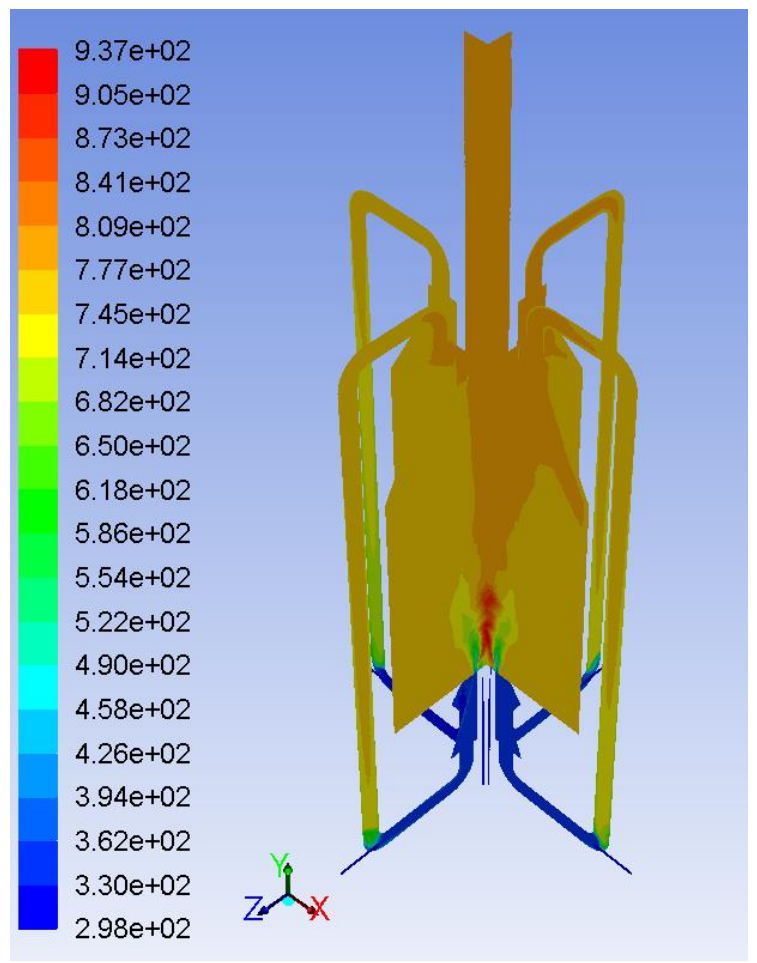

Figure 8. Combustion temperatures not reach MILD combustion state for biogas. Air $\left(21 \% \mathrm{O}_{2}\right)$ inlet at $7.5 \mathrm{~m} / \mathrm{s}$, fuel inlet at $6.8 \mathrm{~m} / \mathrm{s}$. 


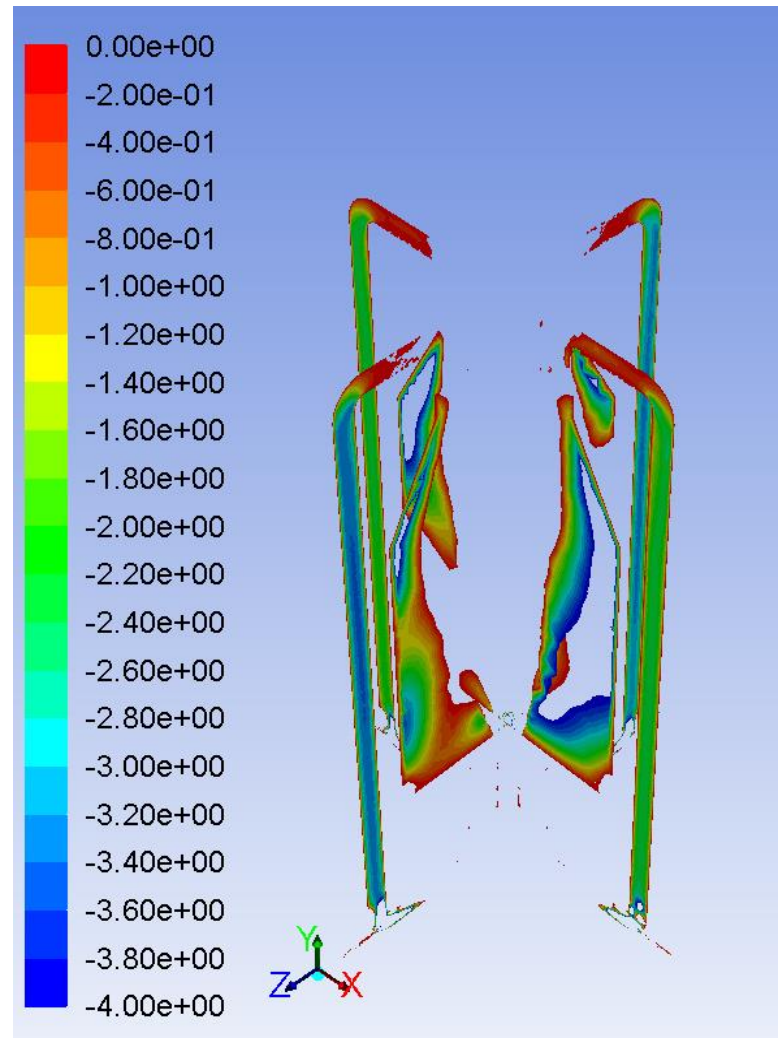

Figure 9. EGR pipe flow downward to preheat the reactant

\section{CONCLUSION}

MILD or flameless combustion produces a greater efficiency with lower emissions, and with the use of biogas it completes the $\mathrm{CO}_{2}$ cycle. This type of combustion offers many benefits to the furnace and burner industries. Presently heating industries are in the early stages of the adoption of MILD or flameless technologies for their burners. Most burners still use conventional combustion technology, since conventional combustion is fundamentally stable and there is extensive experience with it. Despite the benefits, the fundamentals of MILD combustion are not properly established and need further research, especially with regard to the control parameters, combustion behavior, combustion characteristics, EGR and dilution required. Biogas and biofuels are the best alternatives for the fuel depletion issue. Fuel from bio resources is very environmentally-friendly since the $\mathrm{CO}_{2}$ cycle is effectively closed. CFD is a good tool to simulate, predict and pre-set the parameters for the pre-experimental work. The results from CFD are promising enough for experiments to take place. A recent trend shows that MILD can be achieved with a closed furnace with internal closed combustion chamber air dilution. The preheating of air is not necessary since it already occurs in the chamber. This will make the construction of the combustion chamber simpler, without the necessity for external EGR. An open furnace with EGR to dilute and pre-heat the oxidant was studied. Numerically MILD combustion was achieved for open MILD combustion. These results need to be validated by experimental techniques and be discussed further. 


\section{ACKNOWLEDGMENTS}

The authors would like to thank the University of Southern Queensland (USQ), and the Ministry of Higher Education, Malaysia (MOHE) for providing financial support and laboratory facilities.

\section{REFERENCES}

Abd-Alla, G.H., Soliman, H.A., Badr, O.A. and Abd-Rabbo, M.F. 2001. Effects of diluents and intake air temperature in exhaust gas recirculation of an indirect injection dual fuel engine. Energy Conversion Management, 42: 1033-1045.

Agarwal, D., Sinha, S. and Agawal, A.K. 2006. Experimental investigation of control of Nox emissions in biodiesel - fuelled compression ignition engine. Renewable Energy, 31: 2356-2369.

Al-Seadi, T., Rutz, D., Prassl, H., Köttner, M., Finsterwalder, T., Volk, S. and Janssen, R. 2008.Biogas handbook. Lemvigbiogas, University of Southern Denmark.

Aminian, J., Galletti, C., Shahhosseini, S. and Tognotti, L. 2011. Key modeling issues in prediction of minor species in diluted-preheated combustion conditions. Applied Thermal Engineering, 31: 3287-3300.

Arghode, V.K. and Gupta, A.K. 2010a. Effect of flow field for colorless distributed combustion (CDC) for gas turbine combustion. Applied Energy, 87(5): 16311640.

Arghode, V.K. and Gupta, A.K. 2010b. Investigation of distributed combustion for gas turbine application: forward flow configuration. ASME Power Conference, Chicago, Illinois.

Arghode, V.K. and Gupta, A.K. 2011a. Investigation of forward flow distributed combustion for gas turbine application. Applied Energy, 88: 29-40.

Arghode, V.K. and Gupta, A.K. 2011b. Development of high intensity CDC combustor for gas turbine engine. Applied Energy, 88: 963-973.

Awosope, I.O., Kandamby, N.H. and Lockwood, F.C. 2006. Flameless oxidation modelling on application to gas turbine combustors. Journal of the Energy Institute, 79(2): 75-83.

Cabra, R., Chen, J.Y., Dibble, R.W., Karpetis, A.N. and Barlow, R.S. 2005. Lifted methane-air jet flames in a vitiated coflow. Combustion and Flame, 143(4): 491-506.

Cabra, R., Myhrvold, T., Chen, J.Y., Dibble, R.W., Karpetis, A.N. and Barlow, R.S. 2003. Simultaneous laser Raman-Rayleigh-LIF measurements and numerical modeling results of a lifted turbulent $\mathrm{H}-2 / \mathrm{N}-2$ jet flame in a vitiated coflow. Proceedings of the Combustion Institute, 29: 1881-1888.

Cavaliere, A. and de Joannon, M. 2004. MILD Combustion. Progress in Energy and Combustion Science, 30: 329-366.

Cavaliere, A., de Joannon, M. and Ragucci, R. 2008. Highly preheated lean combustion. In: Dunn-Derek, D. (ed.) Lean combustion: technology and control. Oxford, UK, Elsevier, pp. 55-94.

Cavigiolo, A., Galbiati, M.A., Effuggi, A., Gelosa, D. and Rota, R. 2003. MILD combustion in a laboratory scale apparatus. Combustion Science and Technology, 175: 1347-1367.

Christo, F.C. and Dally, B.B. 2005. Modeling turbulent reacting jets issuing into a hot and diluted coflow. Combustion and Flame, 142(1-2): 117-129. 
Coelho, P.J. and Peters, N. 2001. Numerical simulation of a MILD combustion burner. Combustion and Flame, 124: 503-518.

Colorado, A.F., Medwell, P.R. and Dally, B.B. 2009. LCV fuels emissions of turbulent nonpremixed jet flames under MILD combustion conditions. Proceedings of the Australian Combustion Symposium (ACS) 2009, University of Queensland, Australia, 2-4 Dec.

Colorado, A.F., Herrera, B.A. and Amell, A.A. 2010. Performance of a flameless combustion furnace using biogas and natural gas, Bioresource Technology 101(7): 2443-2449.

Dally, B.B., Karpetis, A.N. and Barlow, R.S. 2002. Structure of turbulent non-premixed jet flames in a diluted hot coflow. Proceedings of the Combustion Institute, 29(1): 1147-1154.

Dally, B.B, Riesmeier, E. and Peters, N. 2004. Effect of fuel mixture on moderate and intense low oxygen dilution combustion. Combustion and Flame, 137(4): 418431.

Dally, B.B., Shim, S.H., Craig, R.A., Ashman, P.J. and Szego, G.G. 2010. On the burning of sawdust in a MILD combustion furnace. Energy Fuels, 24: 34623470 .

Danon, B. 2011. Furnaces with multiple flameless combustion burners. PhD Thesis. Technische Universiteit Delft, Netherland.

Danon, B., de Jong, W. and Roekaerts, D.J.E.M. 2010. Experimental and numerical investigation of a FLOX combustor firing low calorific value gases, Combustion Science and Technology, 182(9): 1261-1278.

De, A., Oldenhof, E., Sathiah, P. and Roekaerts, D.J.E.M. 2010. Numerical simulation of Delft-jet-in-hot-coflow (DJHC) flames using the eddy dissipation concept model for turbulence-chemistry interaction. Flow, Turbulence and Combustion, doi: 10.1007/s 10494-011-9337-0.

De Joannon, M., Sabia, P., Sorrentino, G. and Cavaliere, A. 2009. Numerical study of MILD combustion in hot diluted diffusion ignition (HDDI) regime. Proceedings of the Combustion Institute, 32(2); 3147-3154.

De Joannon, M., Sabia, P. and Cavaliere, A. 2010. MILD combustion. In: Lackner, M., Winter, F. and Agarwal, A.K., Handbook of combustion, Vol. 5. Weinheim, Wiley-Vch.

Derudi, M., Villani, A. and Rota, R. 2007a. MILD combustion of industrial hydrogencontaining by-products. Industrial and Engineering Chemistry Research, 46: 6806-6811.

Derudi, M., Villani, A. and Rota, R. 2007b. The influence of hydrogen-containing fuels on MILD combustion sustainability. Proceedings of the European Combustion Meeting, Crete, Greece.

Derudi, M., Villani A. and Rota, R. 2007c. Sustainability of MILD combustion of hydrogen containing hybrid fuels. Proceedings of the Combustion Institute, 31: 3393-3400.

Derudi, M. and Rota R. 2011. Experimental study of the MILD combustion of liquid hydrocarbons. Proceedings of the Combustion Institute, 33: 3325-3332.

Duwig, C., Stankovic, D., Fuchs, L., Li, G. and Gutmark, E. 2008. Experimental and numerical study of flameless combustion in a model gas turbine combustor. Combustion Science and Technology, 180(2): 279-295.

Ertesvag, I.S. and Magnussen, B.F. 2000. The eddy dissipation turbulence energy cascade model. Combustion Science and Technology, 159: 213-235. 
Flamme, M. 2004. New combustion systems for gas turbines. Applied Thermal Engineering, 24(11-12): 1551-1559.

Frassoldati, A., Sharma, P., Cuoci, A., Faravelli, T. and Ranzi, E. 2010. Kinetic and fluid dynamics modeling of methane/hydrogen jet flames in diluted coflow. Applied Thermal Engineering, 30: 376-383.

Fuse, R., Kobayashi, H., Ju, Y., Maruta, K. and Niioka, T. 2002. NOx emission from high-temperature air/methane counter flow diffusion flame. International Journal of Thermal Sciences, 41: 693-698.

Galletti, C., Parente, A. and Tognotti, L. 2007. Numerical and experimental investigation of a MILD combustion burner. Combustion and Flame, 151(4): 649-664.

Galletti, C., Parente, A., Darudi, M., Rota, R. and Tognotti, L. 2009. Numerical and experimental analysis of NO emissions from a lab-scale burner fed with hydrogen-enriched fuels and operating in MILD combustion. International Journal of Hydrogen Energy, 34: 8339-8351.

Gupta, A.K. 2000. Flame characteristics and challenges with high temperature air combustion. 2000 International Joint Power Generation Conference Miami Beach, Florida, USA.

Gupta, A.K., Bolz, S. and Hasegawa, T. 1999. Effect of air preheat temperature and oxygen concentration on flame structure and emission. Journal of Energy Resources Technology, 121: 209-216.

Hairuddin, A.A., Wandel, A.P. and Yusaf, T. 2010. Hydrogen and natural gas comparison in diesel HCCI engines - a review, Southern Region Engineering Conference (SREC), Engineers Australia, Toowoomba, Australia. Paper ID: SREC2010-F2-2.

Hasegawa, T., Mochida, S. and Gupta, A.K. 2002. Development of advanced industrial furnace using highly preheated air combustion. Journal of Propulsion and Power, 18(2): 233-239.

Hino, Y., Zhang, C and Ishii, T. 1998. Comparison of measurements and predictions of flame structure and NOx emissions in a gas-fired furnace. AIAA/ASME Joint Thermophysics and Heat Transfer Conference, Albuquerque, New Mexico, USA.

Hollinger, T. and Bose, T. 2008. Hydrogen internal combustion engine. In: Hydrogen Technology, Chapter 7a. Berlin Heidelberg, Springer-Verlag.

Hountalas, D.T., Mavropoulos, G.C. and Binder, K.B. 2008. Effect of exhaust gas recirculation (EGR) temperature for various EGR rates on heavy duty DI diesel performance and emissions. Energy, 33: 272-283.

IEA. 2006. World Energy Outlook. Paris, International Energy Agency.

IEA. 2009. World Energy Outlook. Paris, International Energy Agency.

IEA/OECD. 2002. $\mathrm{CO}_{2}$ emissions from fuel combustion: 1971-2000. Paris, Organisation for Economic Cooperation and Development and the International Energy Agency.

Ishii, T., Zhang, C. and Sugiyama, S. 1997. Numerical analysis of NOx formation rate in a regenerative furnace. Joint Power Generation Conference, Denver, Colorado, USA.

Jonathan, P. 2006. Responses to questions on the design elements of a mandatory market-based greenhouse gas regulatory system. Washington, World Resources Institute. 
Katsuki, M. and Hasegawa, T. 1998. The science and technology of combustion in highly preheated air. Proceedings of the Combustion Institute, 27(2): 3135-3146.

Keramiotis, C. and Founti, M.A. 2013. An experimental investigation of stability and operation of a biogas fueled porous burner, Fuel, 103: 278-284.

Kim, S.H., Huh, K.Y. and Dally, B.B. 2005. Conditional moment closure modeling of turbulent nonpremixed combustion in diluted hot coflow. Proceedings of the Combustion Institute, 30: 751-757.

Kim, J.P., Schnell, U. and Scheffknecht, G. 2008. Comparison of different global reaction mechanisms for MILD combustion of natural gas. Combustion Science and Technology, 180(4): 565-592.

Kong, S.C. and Reitz, R.D. 2002. Use of detailed chemical kinetics to study HCCI engine combustion with consideration of turbulent mixing effects. Journal of Engineering for Gas Turbines and Power - Transactions of the ASME, 124(3): 702-707.

Khoshhal, A., Rahimi, M. and Alsairafi, A.A. 2011. Diluted air combustion and NOx emission in a HiTAC furnace. Numerical Heat Transfer, Part A: Applications, 59 (8): 633-651.

Kraus, B.J. and Barraclough, S. 2012. New configuration may make it harder to say no to thermal regeneration. Industrial Heating, LXXX (1), 24-27.

Kumar, S., Paul, P.J. and Mukunda, H.S. 2007. Prediction of flame liftoff height of diffusion/partially premixed jet flames and modeling of MILD combustion burners. Combustion Science and Technology, 179: 2219-2253.

Launder, B.E. and Sharma, B.I. 1974. Application of the energy dissipation model of turbulence to the calculation of flow near a spinning disc. Letters in Heat and Mass Transfer, 1(2): 131-138.

Li, M., Rao, A.D., Brouwer, J. and Scott, S.G. 2010a. Design of highly efficient coal based IGFC power plants. Journal of Power Sources, 195(17): 5707-5718.

Li, P.F., Mi, J.C., Dally, B.B., Richard, A.C. and Wang, F. 2010b. Effect of equivalence ratio and mixing pattern on flameless combustion. Chinese Society of Engineering Thermophysics Conference, Guang Zhou. Chinese Society of Engineering Thermophysics

Li, P.F. and Mi, J.C. 2010. Critical Reynolds numbers for realization of MILD combustion in a recuperative furnace. $8^{\text {th }}$ International Symposium on High Temperature Air Combustion and Classification, Poznan. Poznan University of Technology Press.

Li, P.F. and Mi, J.C. 2011. Influence of inlet dilution of reactants on premixed combustion in a recuperative furnace. Flow, Turbulence and Combustion, 87: 617-638.

Li P.F., Mi J., Dally, B.B., Craig, R.A. and Wang, P. F. 2011a. Premixed moderate or intense low-oxygen dilution (MILD) combustion from a single jet burner in a lab-scale furnace. Energy Fuels, 25: 2782-2793.

Li, P.F., Mi, J.C., Dally, B.B., Wang, F.F., Wang, L., Liu, Z.H., Chen, S. and Zheng, C. G. 2011b. Progress and recent trend in MILD combustion. Science China Technological Sciences, 54: 255-269.

Lou, B., Luo, Y.H. and Ma, X.Q. 2007. Model and experimental validation on NOx emission of biomass combustion in rotary kiln with HTAC. Proceedings of the CSEE, 27(29): 68-73.

Maczulak, A. 2010. Renewable energy, sources and methods. New York, USA, Facts on File Inc. 
Mancini, M., Schwoppe, P., Weber, R. and Orsino, S. 2007. On mathematical modelling of flameless combustion. Combustion and Flame, 150(1-2): 54-59.

Mancini, M., Weber, R. and Bollettini, U. 2002. Predicting NOx emissions of a burner operated in flameless oxidation mode. Proceedings of the Combustion Institute, 29 (1): 1155-1163.

Mardani, A. and Tabejamaat, S. 2010. Effect of hydrogen on hydrogenemethane turbulent non-premixed flame under MILD condition. International Journal of Hydrogen Energy, 35: 11324-11331.

Mardani, A., Tabejamaat, S. and Ghamari, M. 2010. Numerical study of influence of molecular diffusion in the MILD combustion regime. Combust Theory Model, 14: 747-774.

Maruta, K., Muso, K., Takeda, K. and Niioka, T. 2000. Reaction zone structure in flameless combustion. Proceedings of the Combustion Institute, 28: 2117-2123.

Medwell, P.R. 2007. A laser diagnostic on MILD combustion. PhD Thesis, University of Adelaide, Australia.

Medwell, P.R., Kalt, P.A.M. and Dally, B.B. 2007. Simultaneous imaging of OH, formaldehyde, and temperature of turbulent nonpremixed jet flames in a heated and diluted coflow. Combustion and Flame, 148(1-2): 48-61.

Medwell, P.R., Kalt, P.A.M. and Dally, B.B. 2008. Imaging of diluted turbulent ethylene flames stabilized on a Jet in Hot Coflow (JHC) burner. Combustion and Flame, 152(1-2): 100-113.

Merci, B., Naud, B. and Roekaerts, D. 2007. Impact of turbulent flow and mean mixture fraction results on mixing model behaviour in transported scalar PDF simulations of turbulent non-premixed bluff body flames flow. Turbulence and Combustion, 79: 41-53.

Mi, J.C., Li, P.F. and Zheng, C.G. 2010. Numerical simulations of flameless premixed combustion in a recuperative furnace. Chinese Journal of Chemical Engineering, 18(1): 10-17.

Mi, J.C., Li, P.F., Dally, B.B., Wang, F.F., Wang, L., Liu, Z.H., Chen, S. and Zheng, C.G. 2009. Importance of initial momentum rate and air-fuel premixing on moderate or intense low oxygen dilution (MILD) combustion in a recuperative furnace. Energy Fuels, 23(11): 5349-5356.

Milani, A. and Wünning, J.G. 2007. Flameless oxidation technology, advanced combustion and aero thermal technologies, Environmental Protection and Pollution Reductions, 6: 343-352.

Mollica, E., Giacomazzi, E. and Di Marco, A. 2009. Numerical study of hydrogen MILD combustion, Thermal Science, 13(3): 59-67.

Mörtberg, M., Blasiak, W., and Gupta, A.K. 2006. Combustion of normal and low calorific fuels in high temperature and oxygen deficient environment, Combustion Science and Technology, 178: 1345-1372.

Mörtberg, M., Blasiak, W. and Gupta, A.K. 2007. Experimental investigation of flow phenomena of a single fuel jet in cross-flow during highly preheated air combustion conditions. Journal of Engineering for Gas Turbines and Power, 129: 556-564.

Mullinger, P. and Jenkins, B. 2008. Industrial and process furnaces: principles, design and operation. Oxford, UK, Elsevier.

Nakamura, T., Smart, J.P. and Van de Kamp, W.L. 1993. The effect of fuel air mixing on NOx reduction and heat transfer in high temperature gas fired glass melting 
furnaces. Combustion and emissions control. Cardiff, UK, Institute of Energy, pp. 213-230.

Noor, M.M., Yusaf, T.F. and Wandel A.P. 2011. Study of random particle interactions for analysis of diffusion lengths in turbulent combustion modeling. Proceedings of the Australian Combustion Symposium (ACS) 2011, University of Newcastle, Australia, 29 Nov.-1 Dec., Paper ID: 2011-36.

Noor, M.M., Wandel, A.P. and Yusaf, T.F. 2012a. A preliminary study of control parameters for open furnace MILD combustion using CFD. Malaysian Postgraduate Conference (MPC) 2012, Bond University, Australia, 7-9 July, Paper No.: MPC2012-16.

Noor, M.M., Wandel, A.P. and Yusaf, T.F. 2012b. The modeling of the effect of air fuel ratio on unburned hydrocarbons for MILD combustion. Malaysian Postgraduate Conference (MPC) 2012, Bond University, Australia, 7-9 July, Paper No.: MPC2012-27.

Noor, M.M., Wandel, A.P. and Yusaf, T.F. 2012c. The study of air fuel ratio for mild combustion of biogas on bluff-body burner, Southern Regional Engineering Conference (SREC), Engineers Australia, University of Southern Queensland (USQ), Australia. Paper ID: SREC2012-MMNoor1.

Noor, M.M., Wandel, A.P. and Yusaf, T.F. 2012d. Numerical investigation of influence of air and fuel dilution for open furnace mild combustion burner, Southern Regional Engineering Conference (SREC), Engineers Australia, 1-2 Sept, University of Southern Queensland, Australia, Paper No. SREC2012-002.

Oldenhof, E., Tummers, M.J., van Veen, E.H. and Roekaerts, D.J.E.M. 2010. Ignition kernel formation and lift-off behaviour of jet-in-hot-coflow flames. Combustion and Flame, 157(6): 1167-1178.

Oldenhof, E., Tummers, M.J., van Veen, E.H. and Roekaerts, D.J.E.M. 2011. Role of entrainment in the stabilisation of jet-in-hot-coflow flames. Combustion and Flame, 158: 1553-1563.

Olsson, J.O., Tunesta, P., Johansson, B., Fiveland, S.B., Agama, R., Willi, M. and Assanis, D.N. 2002. Compression ratio influence on max load of a natural gas fuelled HCCI engine. SAE Paper 02P-147.

Orr, F. 2005. Energy and climate: challenges and solutions. GCEP, Stanford University.

Oryani, H., Khalilarya, S., Jafarmadar, S., Khatamnezhad, H. and Majidyfar, S. 2011. Numerical investigation of influence of dilution in air and fuel sides on MILD combustion burner. Australian Journal of Basic and Applied Science, 5(10): 272-279.

Özdemir, I.B. and Peters, N. 2001. Characteristics of the reaction zone in a combustor operating at MILD combustion. Experiments in Fluids, 30: 683-695.

Papagiannakis, R.G. and Hountalas, D.T. 2004. Combustion and exhaust emission characteristics of a dual fuel compression ignition engine operated with pilot diesel fuel and natural gas. Energy Conversion and Management, 45(18-19): 2971-2987.

Parente, A., Galletti, C. and Tognotti, L. 2008. Effect of the combustion model and kinetic mechanism on the MILD combustion in an industrial burner fed with hydrogen enriched fuels. International Journal of Hydrogen Energy, 33: 75537564.

Parente, A., Galletti C. and Tognotti L. 2011. A simplified approach for predicting NO formation in MILD combustion of $\mathrm{CH}_{4} / \mathrm{H}_{2}$ mixtures. Proceedings of the Combustion Institute, 33, 3343-3350. 
Parente, A., Sutherland, J.C., Dally, B.B., Tognotti, L. and Smith, P.J. 2009. Investigation of the MILD combustion regime via principal component analysis. Proceedings of the Australian Combustion Symposium (ACS) 2009, University of Queensland, Australia, Paper ID: 2009-21.

Parente, A., Sutherland, J.C., Dally, B.B., Tognotti, L. and Smith, P.J. 2011. Investigation of the MILD combustion regime via principal component analysis. Proceedings of the Combustion Institute, 33: 3333-3341.

Parham, J.J., Nathan, G.J., Smart, J.P., Hill, S.J. and Jenkins, B.G. 2000. The relationship between heat flux and $\mathrm{NO}_{\mathrm{x}}$ emissions in gas fired rotary kilns. Journal of the Energy Institute, 73: 25-34.

Park, J., Choi, J.W., Kim, S.G., Kim, K.T., Keel, S.I. and Noh, D.S. 2004. Numerical study on steam-added MILD combustion. International Journal of Energy Research, 28: 1197-1212.

Park, J., Hwang, D., Choi, J., Lee, K., Keel, S. and Shim, S. 2003. Chemical effects of $\mathrm{CO}_{2}$ addition to oxidizer and fuel streams on flame structure in $\mathrm{H}_{2} / \mathrm{O}_{2}$ counterflow diffusion flames. International Journal of Energy Research, 27: 1205-1220.

Peters, N. 2000. Turbulent combustion, 1st ed. Cambridge, Cambridge University Press.

Plessing, T., Peters, N. and Wünning, J.G. 1998. Laser optical investigation of highly preheated combustion with strong exhaust gas recirculation. Proceedings of the Combustion Institute, 27(2): 3197-3204.

Pope, S.B. 1985. PDF method for turbulent reactive flows. Progress in Energy and Combustion Science, 11(2): 119-192.

RACQ. 2008. Biofuels: suitability and sustainability. Australia, Royal Automobile Club of Queensland Public Policy Department.

Rafidi, N. and Blasiak, W. 2006. Heat transfer characteristics of HiTAC heating furnace using regenerative burners. Applied Thermal Engineering, 26: 2027-2034.

Raj, C. and Sendilvelan, S. 2010. Effect of oxygenated hydrocarbon additives on exhaust emission of a diesel engine, International Journal of Automotive and Mechanical Engineering, 2:144-156.

Sabia, P., de Joannon, M., Fierro, S., Tregrossi, A. and Cavaliere, A. 2007. Hydrogenenriched methane MILD combustion in a well stirred reactor. Experimental Thermal and Fluid Science, 31: 469-475.

Santoh, K., Zhang, L., Hatanaka, H., Takatsuki, T. and Yokoto, K. 1997. Relationship between NOx and SM emissions from DI diesel engine with EGR. Society of Automotive Engineers of Japan, 18: 369-375.

Scragg, A.H. 2009. Biofuels: production, application and development. Oxfordshire, UK. CAB Int.

Shabanian, S.R., Derudi, M., Rahimi, M., Frassoldati, A., Cuoci, A. and Faravelli, T. 2011. Experimental and numerical analysis of syngas MILD combustion. $34^{\text {th }}$ Italian Section Meeting, Combustion Institute, Italy.

Shafiee, S., Topal, E. 2009. When will fossil fuel reserves be diminished. Energy Policy, 37(1): 181-189.

Smith, S.T. and Fox, R.O. 2007. A term-by-term direct numerical simulation validation study of the multi environment conditional PDF model for turbulent reacting flows. Physics of Fluids, 19: 085102.

Stankovic, D. 2006. Experimental study of flameless combustion in gas turbine combustors. $44^{\text {th }}$ AIAA Aerospace Sciences Meeting and Exhibit, Reno, USA. 
Suzukawa, Y., Sugiyama, S., Hino, Y., Ishioka, M. and Mori, I. 1997. Heat transfer improvement and NOx reduction by highly preheated air combustion. Energy Conversion and Management, 38: 1061-1071.

Szegö, G.G. 2010. Experiment and numerical investigation on a parallel jet MILD combustion burner system in a laboratory scale furnace. PhD Thesis, University of Newcastle, Australia.

Szegö, G.G., Dally, B.B. and Christo, F.C. 2011. Investigation of the mixing patterns inside a MILD combustion furnace based on CFD modeling. Proceedings of the Australian Combustion Symposium (ACS) 2011, University of Newcastle, Australia, Paper ID: 2011-28.

Szegö, G.G., Dally, B.B. and Nathan, G J. 2008. Scaling of NOx emissions from a laboratory-scale MILD combustion furnace. Combustion Flame, 154: 281-295.

Szegö, G.G., Dally, B.B., Nathan, G.J. and Christo, F.C. 2003. Design optimisation of a mild combustion furnace based on CFD modeling, Australian Symposium on Combustion and the 8th Australian Flame Days, Melbourne, Australia.

Tang, Y., Wu, J., Ma, A., Gou, X., Liu, L. and Wang, E. 2011. Effect of recirculated flue gas position on combustion and NOx emission for high temperature air combustion. IEEE International Conference on Computer Distributed Control and Intelligent Environmental Monitoring, pp. 1177-1180.

Tang, Z.G., Ma, P.Y., Li, Y.L., Tang, C.J., Xing, X.J. and Lin, Q.Z. 2010. Design and experiment research of a novel pulverized coal gasifier based on flameless oxidation technology, Proceedings of CSEE, 30(8): 50-55.

Tennekes, H. and Lumley, J.L. 1972. A first course in turbulence. USA, MIT Press.

Thomas, C.E. 2011. Process technology equipment and systems. NY, USA, Delmar Cengage.

Tsuji, H., Gupta, A., Hasegawa, T., Katsuki, M., Kishimoto, K. and Morita, M. 2003. High temperature air combustion, from energy conservation to pollution reduction. Boca Raton, FL, CRC Press.

Wandel, A.P. 2011. A stochastic micromixing model based on the turbulent diffusion length scale. Proceedings of the Australian Combustion Symposium (ACS) 2011, University of Newcastle, Australia, Paper ID: ACS2011-20.

Wang, F., Mi, J., Li, P. and Zheng, C. 2011. Diffusion flame of a CH4/H2 jet in hot low-oxygen coflow. International Journal of Hydrogen Energy, 36: 9267-9277.

Webber, R. 2001. Combustion of natural gas, oil and coal with air preheated to temperatures in excess of $1000^{\circ} \mathrm{C}$. $13^{\text {th }}$ IFRF Members Conference, Noordwijkerhout, Netherlands, Paper 9.

Weber, R., Orsino, S., Lallemant, N. and Verlann, A. 2000. Combustion of natural gas with high-temperature air and large quantities of flue gas. Proceedings of the Combustion Institute, 28: 1315-1321.

Wünning, J. 1991. Flammenlose oxidation von Brennstoff mit hochvorgewärmter Luft. Chemie Ingenieur Technik, 63(12): 1243-1245.

Wünning, J.G. 1996. Flammlose oxidation von Brennstoff. PhD Thesis, University of Technology, Aachen.

Wünning, J.A. and Wünning, J.G. 1997. Flameless oxidation to reduce thermal noformation. Progress in Energy and Combustion Science, 23(1): 81-94.

Yu, Y., Wang, G., Lin, Q., Ma, C. and Xing, X. 2010. Flameless combustion for hydrogen containing fuels. International Journal of Hydrogen Energy, 35: 26942697. 
Yuan, J.W. and Naruse, I. 1999. Effects of air dilution on highly preheated air combustion in a regenerative furnace. Energy Fuels, 13(1): 99-104.

Zhang, C., Ishii, T. and Sugijama, S. 1997. Numerical modeling of the thermal performance of regenerative slab reheating furnaces. Numerical Heat Transfer, 32: 613-631.

Zhenjun, C., Tong, Z. and Chaohua, J. 2010. Thermal and emission characteristics of high temperature air combustion: a technical review, Mechanic Automation and Control Engineering (MACE), Tongji University, Shanghai, 200092, China.

Zieba, M., Brink, A., Schuster, A., Hupa, M. and Scheffknecht, G. 2010. Ammonia chemistry in a flameless jet Combustion and Flame, 156(10): 1950-1956.

\begin{tabular}{|c|c|}
\hline \multicolumn{2}{|c|}{ Nomenclature } \\
\hline CCS & Carbon capture and storage \\
\hline CFD & Computational fluid dynamics \\
\hline $\mathrm{CMC}$ & Conditional moment closure \\
\hline $\mathrm{CO}$ & Carbon monoxide \\
\hline $\mathrm{CO}_{2}$ & Carbon dioxide \\
\hline $\mathrm{C}_{\mathrm{p}}$ & Specific heat at constant pressure \\
\hline FGR & Flue gas recirculation \\
\hline $\mathrm{GHG}$ & Greenhouse-gas \\
\hline $\mathrm{H}_{2} \mathrm{O}_{2}$ & Hydrogen peroxide \\
\hline $\mathrm{HC}$ & Hydrocarbon \\
\hline HiTAC & High temperature air combustion \\
\hline HTOC & High temperature combustion \\
\hline IEA & International Energy Agency \\
\hline $\mathrm{JHC}$ & Jet in hot coflow \\
\hline LES & Large eddy simulation \\
\hline $\begin{array}{l}\text { MILD } \\
\text { dilution }\end{array}$ & Moderate or intense low $\mathrm{O}_{2}$ \\
\hline $\mathrm{NO}_{\mathrm{x}}$ & Nitrogen oxides \\
\hline $\mathrm{OH}$ & Hydroxyl \\
\hline PDF & Probability density function \\
\hline $\mathrm{SO}_{\mathrm{x}}$ & Sulfur oxides \\
\hline SPDL & Stochastic particle diffusion length \\
\hline UHC & Unburned hydrocarbons \\
\hline
\end{tabular}

\section{Symbols}

$\begin{array}{ll}\mathrm{B} & \text { Diffusion coefficient } \\ \mathrm{K}_{\mathrm{T}} & \text { Total number of particles } \\ \overline{\mathrm{W}} & \text { Mean molecular weight of mixture } \\ \mathrm{W}_{\mathrm{I}} & \text { Molecular weight of species I } \\ \dot{\mathrm{q}} & \text { Heat release rate } \\ \mathrm{M} & \text { Interaction matrix } \\ \mathrm{N} & \text { Total number of species } \\ \mathrm{P} & \text { Favre joint PDF of composition }\end{array}$

$\begin{array}{ll}\mathrm{P}_{\mathrm{b}} & \text { Position of particle } \\ \mathrm{R} & \text { Gas constant } \\ \mathrm{R}_{\mathrm{d}} & \text { Internal dilution ratio } \\ \mathrm{T} & \text { Temperature } \\ \mathrm{T}_{\mathrm{c}} & \text { Chamber temperature } \\ \mathrm{U} & \text { Internal energy } \\ \mathrm{V} & \text { Volume } \\ \mathrm{K}_{\mathrm{v}} & \text { Dilution ratio } \\ \mathrm{Y} & \text { Mass fraction } \\ \mathrm{Z} & \text { Mixture fraction } \\ \mathrm{d} & \text { Constant } \\ \mathrm{k} & \text { Turbulence kinetic energy } \\ \mathrm{m}_{\mathrm{in}} & \text { Mass flow rate } \\ \mathrm{u} & \text { Velocity } \\ \mathrm{V} & \text { Specific volume } \\ \mathrm{w} & \text { Importance weight }\end{array}$

\section{Greek Symbols}

$\mathrm{u}_{\mathrm{i}} \quad$ Favre mean fluid velocity vector

$\delta$ t Time interval

$\mathrm{S}_{\mathrm{k}} \quad$ Reaction rate for species $\mathrm{k}$

$\varepsilon \quad$ Dissipation rate

$\psi_{\mathrm{k}} \quad$ Composition space vector for species $\mathrm{k}$

$\mathrm{u}_{\mathrm{i}}^{\prime \prime} \quad$ Fluid velocity fluctuation vector

$\mathrm{J}_{\mathrm{i}, \mathrm{k}} \quad$ Molecular diffusion flux vector

$v \quad$ Kinematic viscosity

$\xi \quad$ Reference variable

$\rho \quad$ Density or mean fluid density

$\emptyset \quad$ Composition of particle

$\dot{\omega}$ Chemical reaction rate

$\beta \quad$ Index of composition variable

$\alpha \quad$ Model parameter 